\title{
IN ORDER THERE TO FIND GOD: KIERKEGAARD AND OBJECTIVE REVELATION
}

\author{
John Tallach
}

\begin{abstract}
Summary
Kierkegaard is widely regarded as having no time for the objective, with all that this would imply for his view of God's revelation of himself. This article suggests that Kierkegaard's rejection of the objective will be misunderstood unless it is placed within the context of his debate with Hegelian rationalism. This suggestion is then brought to bear on how Kierkegaard has been interpreted by Don Cupitt and by Robert Adams. There is a brief final section on the Kierkegaardian principle that the truth is personal.
\end{abstract}

\section{Introduction}

The view is sometimes expressed that Kierkegaard had no time for God's objective revelation of himself. And it is not difficult to see how readers of Kierkegaard could arrive at such a view. In the Concluding Unscientific Postscript ${ }^{1}$ he wrote 'Objectively, Christianity has absolutely no existence' (p. 116); 'Objectively, there is no truth' (p. 201).

However, I would suggest that in such statements Kierkegaard is using 'objective' in a specialised sense. He often uses this term (as well as others, like 'systematic' and 'speculative') to indicate the whole approach to philosophy and to Christianity which Kierkegaard perceives Hegel and others to have adopted.

${ }^{1}$ Concluding Unscientific Postscript, translated by David F. Swenson \& Walter Lowrie (Princeton: Princeton University Press, 1941). Throughout the remainder of this article, when only page numbers are given, the reference is to this work. 
Taking 'objective' in the non-specialised sense of something which exists independently of our perception of it, something which obtains whether or not anyone believes that it does, I would say that Kierkegaard not only believed in but attached the greatest possible importance to God's objective revelation of himself. In his view, it is specifically God's objective revelation of himself in the Incarnation which confronts man with his finitude and precipitates either the acceptance of faith or the offence of unbelief. Kierkegaard is renowned for his emphasis on the subjective. What is not so widely appreciated is his emphasis on how dependent we are on an objective God for producing the kind of subjectivity which is present when we respond in an appropriate way to God's revelation of himself.

Now, if the learner is to acquire the Truth, the Teacher must bring it to him; and not only so, but he must also give him the condition necessary for understanding it. . .And still we have not said all that is necessary; for by his self-imposed bondage the learner has brought upon himself a burden of guilt, and when the Teacher gives him the condition and the Truth he constitutes himself an Atonement, taking away the wrath impending upon that of which the learner has made himself guilty. ${ }^{2}$

\section{Kierkegaard's Calling}

Kierkegaard apparently hoped, after exercising a corrective influence in some areas where he believed the church to have gone badly wrong, to retire from controversy and to spend his time quietly as the pastor of a congregation somewhere in the Danish countryside. But this dream never became a reality. After his first clash with the established Christian church in Denmark his life became increasingly dominated by controversy, and his criticisms became increasingly strident until his death in November 1855. During his life he was caricatured, lampooned and ridiculed. His writings were regarded as the unbalanced outpourings of an embittered soul. Soren

2Philosophical Fragments, translated by David F. Swenson \& H.V. Hong (Princeton: Princeton University Press, 1967) 17 and 21. 
Kierkegaard was someone whom history would soon forget. But in fact the opposite has taken place.

Is it possible to say what Kierkegaard himself saw as his calling? For answer, I would point to three passages in the Postscript. On page 216 Kierkegaard describes his task as to discover where the misunderstanding lies between speculative philosophy and Christianity'. At an earlier stage in the book, Kierkegaard describes how he sat one afternoon at the cafe in the Frederiksberg Garden and thought about how others were achieving fame and were earning the blessing of mankind by making things easier. At this point his cigar went out, so he lit another, and suddenly it occurred to him: 'You must do something...to make something harder' (p. 166). Earlier still, Kierkegaard presents the focal point of the book as being: 'How may I participate in the happiness promised by Christianity?' (p. 20).

What does Kierkegaard mean when he speaks about the 'misunderstanding' between philosophy and Christianity? $\mathrm{He}$ is here setting himself against the kind of relationship between philosophy and Christianity which Descartes and Hegel put forward. Descartes professed to have stripped down an outmoded and uncertain approach to knowledge and to have built things up again from a more sure foundation. The certainty of God's existence was built into this new construction. Descartes saw a logical development from knowledge of mathematical truths to knowledge of ourselves to knowledge of God. His confidence was such that he wrote,

I dare to boast that I have found a proof of the existence of God which I find fully satisfactory and by which I know that God exists more certainly than I know the truths of any geometrical proposition. ${ }^{3}$

In Hegel's philosophy, the Absolute Idea expressed truth through religion in a symbolical form (although, at a later stage, religion would be superseded and truth would be expressed directly through philosophy).

Kierkegaard was totally opposed to both of these perceptions of the relationship between philosophy and

${ }^{3}$ Discourse on Method and The Meditations, translated by F.E. Sutcliffe (Harmondsworth: Penguin, 1968) 20. 
Christianity. He rejected Descartes' suggestion that our thinking about God could be considered as on the same plane with our thinking about mathematics. It was essential, in Kierkegaard's view, to grasp that there is a great gulf between the type of thinking appropriate to mathematics and the type of thinking appropriate to the gospel.

It is not denied that objective thought has validity; but in connection with all thinking where subjectivity must be accentuated, it is a misunderstanding. If a man occupied himself, all his life through, solely with logic, he would nevertheless not become logic...existence itself mocks everyone who is engaged in becoming purely objective (8586).

Kierkegaard felt it was offensive in the extreme for Hegel to suggest that, although Christianity did have a place in his system, it only functioned as one stage on man's pilgrimage towards absolute knowledge.

The objective faith-it is as if Christianity also had been promulgated as a little system, if not quite so good as the Hegelian; it is as if Christ-aye, I speak without offence-it is as if Christ were a professor, and as if the Apostles had formed a little scientific society (p. 193).

What does Kierkegaard mean when he says he felt called 'to make something harder'? He means that, in reaction against the picture presented by Descartes and Hegel, he wanted to show that Christianity is something other than a sum of propositions which fits neatly into a complete logical system; and that man himself is something more complex than can be fitted within Descartes' definition: 'only a thing which thinks, that is to say, a mind, understanding, or reason'. 4 In Kierkegaard's view, it is essential for us to apprehend 'the doubleness characteristic of existence' (p. 69). Man is a mixture of the temporal and the eternal. In the existing individual, various opposing factors operate in tension with one another. Any knowledge of the type where the subjective element is important is possible only when these opposing forces act and react against one another in

4Discourse, 105. 
the experience of the individual. Any attempt to provide a comprehensive, systematic, exhaustive account of truth involves a refusal to face up to man as he really is. It involves an attempt to break free from that tension which is native to our present existence; an attempt to speak from a perspective where in fact we have no standing place. ${ }^{5}$

How does all this fit in with the question posed in the Introduction to the Postscript about becoming a Christian? Once we have faced the paradox which we are, once we have despaired of being delivered from the pain of our finitude by some pseudo-Christianity which really involves the idolatrous worship of human reason, Kierkegaard invites us to look to the Paradox of the God in time. There, the eternal meets the temporal, and the Paradox of the God in time speaks to the paradox which we are. It is in facing the gospel as it is that we are strengthened to face ourselves as we are.

\section{Interpreting Kierkegaard}

\section{Don Cupitt}

Don Cupitt advocates an extremely subjective view of religion. He presents a picture in which all concern about the existence of an objective personal God belongs to the past. As we grow towards religious maturity, Cupitt says, we must accept that God is nothing more than the projection of our ideal. 'So far as we can tell', he says, 'there is no objective personal God.' 6 In chapters 8 and 9 of Taking Leave of God, Cupitt argues against the concept of an unchangeable personal God, against the belief that God personally hears prayer, and against the doctrine of immortality. What, then, is left?

\footnotetext{
${ }^{5}$ Kierkegaard is not the only one to have reacted against the splendid unreality of the Hegelian system. Simone de Beauvoir wrote: 'I remember having felt a great calm in reading Hegel in the impersonal setting of the Bibliothèque Nationale, in August 1940. But when I found myself again in the street, in my life, outside the system, under the real sky, the system was no longer any use to me; it was, under the pretext of the infinite, the consolations of death which it offered me; and I still wanted to live in the midst of living men' (taken from H.J. Blackham, Six Existentialist Thinkers [London: Routledge \& Kegan Paul, 1961] 44).

6Taking Leave of God (London: SCM, 1980) 93.
} 
Every human being who is serious about existence, who is not content to drift with the crowd towards death but seeks to set himself high ideals and to make his life something of worth, must formulate his own idea of God as the unifying symbol of the life-aim to which he is devoted. ${ }^{7}$

The relevance of Don Cupitt's views here is that he claims to have support for this extreme religious subjectivity from the writings of Kierkegaard. 'The plain man's notion that there is "literally" a life after death...never arises and cannot arise from Kierkegaard's point of view.'8 When discussing the views of Jung, Cupitt says that, if we ask a question like 'Does Jung really believe in God?' we are asking the wrong question. To ask such a question implies the assumption that the realist view of the meaning of God is in possession of the field'. 9

Although Kierkegaard no doubt left himself open to misunderstanding and misuse, I would suggest that the evidence is clearly there in Kierkegaard's writings that Cupitt's interpretation is without support. On the doctrine of immortality, Kierkegaard wrote:

The speculative movement which plumes itself on having completely understood Christianity, and explains itself at the same time as the highest development within Christianity, has strangely enough made the discovery that there is no 'beyond'. The notions of a future life, of another world, and similar ideas, are described as arising out of the dialectical limitations of the finite understanding. The conception of a future life has become a jest, a claim so precarious that no one honours it, nay, no one ever any longer even issues it; it tickles our sense of humour to consider that there was once a time when this conception transformed the whole of life (p. 323).

Kierkegaard here ironically distances himself from the attitude adopted by Cupitt towards the traditional Christian teaching on the after-life. In fact, the view adopted by Cupitt is one which Kierkegaard sees as emerging from an application of the principles of speculative philosophy to Christianity. There can hardly be any stronger condemnation in Kierkegaard than that.

${ }^{7}$ The Sea of Faith (London: BBC Publications, 1985) 247.

${ }^{8}$ Cupitt, The Sea of Faith, 153.

${ }^{9}$ Cupitt, The Sea of Faith, 231. 
On the question of the existence of an objective, personal God, Kierkegaard again takes up a position which is the very opposite of that adopted by Cupitt:

A believer is one who is infinitely interested in another's reality. This is a decisive criterion for faith, and the interesting question is not just a little curiosity, but an absolute dependence upon faith's object. The object of faith is the reality of another, and the relationship is one of infinite interest...the object of faith is the reality of the Teacher, that the teacher really exists. The answer of faith is therefore unconditionally yes or no... The maximum of attainment within the sphere of the intellectual, namely, to realise an entire indifference as to the reality of the Teacher, is in the sphere of faith at the opposite end of the scale. The maximum of attainment within the sphere of faith is to become infinitely interested in the reality of the Teacher (pp. 290-291).

Kierkegaard makes a distinction which is central to his view of what constitutes true Christianity. This is the distinction between Religiousness A and Religiousness B (or Christianity). Kierkegaard describes Religiousness $A$ as 'the religiousness of immanence' (p. 496). By this Kierkegaard means, I think, that Religiousness A is a religiousness which can operate without having access to resources beyond what is available to man in a natural way (i.e., without the intervention of what could be called supernatural grace). Kierkegaard then goes on:

But why then call it Christian? Christianity is not content to be an evolution within the total definition of human nature...Of Religiousness A one may say that, even if it has not been exemplified in paganism, it could have been, because it has only human nature in general as its assumption...

The only edification, or building up, available in the sphere of Religiousness $\mathrm{A}$ is a further drawing out of what is already within human nature or a further employment of what is already accessible to it in a natural way. By contrast,

...in Religiousness $B$ the edifying is a something outside the individual, the individual does not find edification by finding the God-relationship within himself, but relates himself to something outside himself to find edification (p. 498). 
Religiousness A is precisely the kind of religiousness which Cupitt seeks to promote. This is the religiousness which results when the principles of speculative philosophy are applied to Christianity, producing a religion which is essentially mancentred and is not essentially different from paganism. The difference between Kierkegaard and Cupitt is that Kierkegaard could and did say, while Cupitt does not and cannot say: 'By me therefore Religiousness A has never been called Christian or Christianity' (p. 498).

One of Cupitt's comments on Kierkegaard which I find most extraordinary is the following:

Kierkegaard de-mythologised Christianity into spirituality, and did so quite naturally, without any special effort, because living as he did after the Enlightenment, after Kant's demolition of dogmatic metaphysics, and in the shadow of idealist philosophy, all the problems with which he was concerned presented themselves to him as problems in spirituality. It came quite naturally to him to think that everything is decided within the sphere of human subjectivity. All the different ways of life that he discusses, aesthetic, ethical, religious and Christian, appear simply as various possible forms of consciousness, shapes that the human spiritual life may assume and worlds that it may construct around itself. None was assessed in terms of its correspondence with objective facts and structures out there; all were assessed from within, and in terms of their inner logic and movement. ${ }^{10}$

It is untrue to Kierkegaard to suggest that the Christian way of life represents a world which the human spirit creates around itself. But what I find remarkable about this comment by Cupitt is his apparent implication that Kierkegaard was indebted to Kant, and learned his subjectivism from him. Cupitt's picture is that Kant imparted an irreversible anthropocentric thrust to all subsequent responsible thinking, and that Kierkegaard appreciated this and went along with it. This is totally alien to the overall direction of Kierkegaard's work, and specifically to the dismissive reference on page 292 of the Postscript to 'Kant's misleading reflection which brings reality into connection with thought'. In Kierkegaard's account, reality is not moulded by

${ }^{10}$ Cupitt, The Sea of Faith, 153. 
human thought. On the contrary, we are stirred up to begin to think as existing individuals when we come up against reality, particularly the realities of the Christian sphere. Genuine subjectivity, in Kierkegaard's view, only comes about when an individual responds in an appropriate way to an encounter with the objective. In fact, subjectivity represents for Kierkegaard the only way forward towards a growing relationship with the objective. How much further apart could Cupitt and Kierkegaard be?

\section{Robert Adams}

There are several reasons why Kierkegaard's work tends to be interpreted in markedly differing ways. One of these is his belief that, in matters where the subjective is to be accentuated, the only appropriate method of communication is an indirect one. To put this perhaps rather bluntly, when there is something really important to be said, we cannot say it.11 If Kierkegaard's method of communicating the really important things is an indirect one, this factor alone makes it likely that different people will come away from reading Kierkegaard with differing views as to what he is saying. ${ }^{12}$

We can, in a sense, approach Kierkegaard too seriously. Using the tools and techniques of analytical philosophy, we can find it difficult to come to grips with the work of a man who wrote a thesis on The Concept of Irony, and who himself often wrote in an ironical style. We can find ourselves examining a passage with great care, only to realise on reflection that he is sending his subject up. He even sends up himself. Kierkegaard is at times exceedingly careful in his use of terms, and at other times he is careless. He combines the coldly clinical with the artistic. He is at times very withdrawn and then he is expan-

\footnotetext{
${ }^{11} C f$. the parallel between what Kierkegaard says about the difference between direct and indirect communication and what Wittgenstein says about the difference between what can be said and what can only manifest itself: 'There are, indeed, things that cannot be put into words. They make themselves manifest. They are what is mystical... What we cannot speak about we must pass over in silence'. L. Wittgenstein, Tractatus LogicoPhilosophicus, translated by D.F. Pears \& B.F. McGinnes (London: Routledge \& Kegan Paul, 1974) 6.622 and 7.

${ }^{12}$ Another factor making for misunderstanding of Kierkegaard is that we can read back into his writings the views of other existentialist thinkers who came after him.
} 
sive, painting a picture with the bold strokes of a broad brush. Perhaps the best we can do is to seek to establish what the main points are which Kierkegaard is making, and to interpret individual details from his writings in the light of these points. It may be that, the more we think about Kierkegaard, the stronger our conviction will be that he was not concerned to make a lot of points, however voluminous his writings. But we may also come to have a deepening appreciation of just how important those points are which he was so concerned to make.

Robert Adams' views on Kierkegaard are presented in two chapters in his book The Virtue of Faith, and Other Essays in Philosophical Theology. 13

In the chapter entitled 'Kierkegaard's Arguments Against Objective Reasoning in Religion', Adams discusses three arguments which he finds in the Postscript, all three arguments being directed towards supporting the position that it is useless or undesirable to reason objectively in support of faith. In the introductory section, Adams concedes that Kierkegaard uses the word 'objective' in different senses. He then goes on to set out what he takes the sense to be, for example in the passage on page 182 of the Postscript, where Kierkegaard gives us his definition of truth: 'An objective uncertainty held fast in an appropriation-process of the most passionate inwardness'. In what sense does Adams understand 'objective' here? He writes:

Let us say that a piece of reasoning, $R$, is objective reasoning just in case every (or almost every) intelligent, fair-minded, and sufficiently informed person would regard $R$ as showing or tending to show (in the circumstances in which $R$ is used, and to the extent claimed in $R$ ) that $R^{\prime}$ s conclusion is true or probably true'.

Adams does not explain why he takes 'objective' in this sense.

I suggested earlier that, in many cases, Kierkegaard uses words like 'objective' in a specialised sense, as distinct from the straightforward sense in which Adams takes it. I

\footnotetext{
13R.M. Adams, The Virtue of Faith, and Other Essays in Philosophical Theology (Oxford: Oxford University Press, 1987). The chapters concerned are 'Kierkegaard's Arguments against Objective Reasoning in Religion' (pp. 25-41) and 'The Leap of Faith' (pp. 42-47).
} 
suggested that Kierkegaard is using the term to identify the whole approach to how we know (the whole approach to the relationship between us and that which is outside us, the whole approach to philosophy and to truth and to Christianity) which is set out for us in the system of Hegelian rationalism. This is an approach which neglects the subjective factor which, in Kierkegaard's view, is all-important. 'In the objective sense, thought is understood as being pure thought... This objective thought has no relation to the existing subject' (p. 112).

Adams says, in relation to the phrase which Kierkegaard uses in his definition of truth, 'Objective uncertainty is a proposition which cannot be shown by objective reasoning to be certainly true ${ }^{\prime}{ }^{14}$ I would suggest that this is not the way in which we should understand 'objective uncertainty', and would suggest that we should think instead along the following lines. When a person reaches out towards the truth as it presents itself to him, he appropriates it personally, and this is accompanied by at least two things. Firstly he disavows all claims to the kind of 'illusory finality' which the Hegelian philosophy pretends to provide. 'Objective knowledge is placed in abeyance' (p. 182). This is what Kierkegaard means by holding the objective uncertainty fast: the existing individual steadfastly resists the temptation to approach truth in the 'systematic' way of exhaustive definition attempted by speculative philosophy. Secondly, the fact that the existing individual has committed himself to the truth, despite being painfully conscious of his lack of all-round vision, is registered by the deep feeling which accompanies this self-affirming commitment.

Adams' understanding of Kierkegaard's attitude towards 'objective reasoning' can, I believe, be represented as follows: (a) Kierkegaard distances himself from supporting the call to believe which comes to us in the Christian faith by anything which could be described as objective reasoning; (b) however, Kierkegaard's writings contain material which is dependent on the validity of objective reasoning; (c) therefore '...just as Kierkegaard's position has more logical structure than one might at first think, it is more difficult than he proba-

14`Kierkegaard's Arguments against Objective Reasoning in Religion', 26. 
bly realised for him to get away entirely from objective justification.'15

To suggest that Kierkegaard wants to get away entirely from objective justification (in the sense in which Adams uses that phrase) is to suggest that Kierkegaard assigns no place, in his discussion of Christianity, to reason. This is not in fact the case.

In relation to life outwith the Christian sphere, in Kierkegaard's view, it is our capacity to reflect which makes existence such a painful thing. If we floated along without reflection, we could pass from one experience to another in a relatively painless way. It is because our understanding comes into conflict with our experience that existence is painful. It is 'when existence is interpenetrated with reflection' that 'it generates passion' (p. 313). This is the passion and the pain of 'the simple wise man' into whose mouth Kierkegaard puts the words, "The sum total of all my researches amounts at most to this, that I understand that it cannot be otherwise, that it must be impossible to understand' (p. 204). Thus Kierkegaard assigns to reason, as a servant, the role of showing us the limitations of reason. It is when reason seeks to lord it over us that Kierkegaard rages against it. As Stephen Evans says, 'What he fought so passionately was the idolatrous identification of objective thought with man's highest end'.16

This same attitude towards reason (of assigning it a useful role) Kierkegaard carries over into the Christian sphere. Reason is useful to us in our search for God:

Dialectics itself does not see the absolute, but it leads, as it were, the individual up to it, and says: 'here it must be, that I guarantee; when you worship here, you worship God' (pp. 438-9).

Reason continues to be a useful servant as we go on in the Christian way:

${ }^{15}$ 'Kierkegaard's Arguments against Objective Reasoning in Religion', 41.

16C.S. Evans, Subjectivity and Religious Belief (Grand Rapids: Christian University Press, 1978) 75. Cf. what Kierkegaard says ironically on p. 112 of the Postscript: 'Let us not deal unjustly with the objective tendency, by calling it an ungodly and pantheistic self-deification; but let us rather view it as an essay in the comical'. 
Since it is in fact the highest attainment to become and continue to be a Christian, the point of it cannot be to reflect upon Christianity, but only by reflection to intensify the pathos by which one continues to be a Christian (p. 537).

It is true to say, as Adams does, that 'Kierkegaard's position has more logical structure than one might at first think'. But to suggest that Kierkegaard wishes to distance himself altogether from the use of reason ignores those passages in which Kierkegaard explicitly assigns a useful role to reason. It also implies a misunderstanding of what Kierkegaard means when he places a ban on the 'objective'. In these passages he bans reason as something which usurps the throne and which requires the production of a comprehensive, if exhaustive, system. Kierkegaard is happy to admit reason so long as it remains in its own place on 'the stool of wonderment'. ${ }^{17}$

I find it interesting that Adams, when writing outwith the two chapters on Kierkegaard mentioned above, seems to me to be closer to Kierkegaard than when he directly discusses Kierkegaard's work.

What Christianity promises may seem 'too good to be true'; the emotional meaning of this is that Christianity promises more than we can hope for without giving up control. The supreme threat to our control, however, is God himself. In Christian faith we are invited to trust a person so much greater than ourselves that we cannot understand him very fully. We have to trust his power and goodness in general, without having a blueprint of what he is going to do in detail. This is very disturbing because it entails a loss of our control of our own lives. God promises life...In this context the continued lust for control of one's life, in preference to opening oneself to grace, is $\sin ^{\prime} .18$

Later on he says:

The non-manipulative trust that uncertainty makes possible involves a sacrifice of some of our control over our own lives, but it does not necessarily make us less free on the whole. On

17Fragments, 65. Cf. also what Kierkegaard says on p. 73 of the Fragments: '...the Reason sets itself aside and the Paradox bestows itself'.

18'The Virtue of Faith', 20. 
the contrary, it seems to free us to be ourselves in a different way-perhaps because we do not see ourselves as responsible for the outcome in the same way as if we were clinging to a more controlling role. ${ }^{19}$

Adams is not approaching these issues from the same direction as Kierkegaard. But in these statements he puts his finger, in his own way, on some of the points which I would take to be central to the whole of Kierkegaard's work.

\section{The truth is personal}

In this short discussion, I have omitted some important aspects of Kierkegaard's work. However I would suggest that, as we continue to learn from him, we will find that most of what he has to say is organically linked to the principle that the truth is personal.

(a) This means that there is a God-factor in all the knowledge which we have. Kierkegaard states that 'every human being is taught essentially only by God' (p. 92).

(b) This means that our knowledge of ourselves is the reverse side of our knowledge of God. Kierkegaard speaks about the knowledge of God being woven into and working through 'the slightest movement of my consciousness in its solitary communion with itself' (p. 163).

(c) The farther we are from the Christian sphere, the less we are aware of the fact that the truth is personal. But, in the Christian sphere, this principle is spelt out in the call to believe in Christ. In the Incarnation, in which the eternal becomes the temporal, the universal becomes the particular, God takes the materials from which we would love to construct an impersonal system of truth (in order to escape from him) and makes of them someone who says to us, 'I am the truth' (Jn. 14:6). God in Christ has made the fact that truth is personal an inescapable fact. How can we regard the truth as impersonal if we understand that "The object of faith is not the teaching but the teacher'?20

19'The Virtue of Faith', 22.

${ }^{20}$ Fragments, 77 . In view of this, and other similar statements, it seems odd that Adams thinks he can make the point count against Kierkegaard that 
(d) This means that the how is more important than the what. "The objective accent falls on What is said, the subjective accent on How it is said' (p. 181). Kierkegaard is here making the point which has often been made in more ordinary terms by othersthat it is hopeless simply to amass head knowledge about God if we are not changed in our hearts and lives. But he is saying more than that. "The "how" of the individual is an expression just as precise and more decisive for what he has, than is the "what" to which he appeals' (p. 541). He is saying that we should not start by checking the orthodoxy of a man's beliefs and then, somewhat as an afterthought, check that there is a heart and life corresponding to the theoretical orthodoxy. Kierkegaard starts with the How as being even more important than the what of our faith. We can test our real orthodoxy more efficiently by going straight to our subjective state. What impact does the gospel have on us, even if it is only part of the gospel revelation which we have so far grasped?21

(e) This means that truth has a dynamic quality. In the individual's developing relationship with the truth, the individual changes, the perspective from which he views the truth changes, and there is therefore a sense in which there are changes in 'the highest truth attainable' (p. 182) by that individual at that place and time. This is what happens when the individual moves forward from one of Kierkegaard's 'spheres' to another-as from the aesthetical to the ethical, from the ethical to the religious, or from Religiousness A to Christianity. The individual despairs because the framework within which he has been living proves incapable of accommodating the truth as it is opening up to him. But the despair has a positive outcome when the individual has the courage to leap

'the object of religious devotion is not a belief or attitude of one's own, but God' ('Kierkegaard's Arguments...', 32).

${ }^{21}$ Kierkegaard's position seems to me to be supported by Scripture, for example in Pr. 1:7: 'The fear of the Lord is the beginning of knowledge'. Commenting on this verse Derek Kidner says, 'The beginning (i.e. the first and controlling principle, rather than a stage which one leaves behind) is not merely a right method of thought but a right relation: a worshipping submission (fear) to the God of the covenant; who has revealed himself by name (the Lord, i.e., Jahweh). Knowledge, then, in its full sense, is a relationship, dependent on revelation and inseparable from character' (Proverbs: Introduction and Commentary [Leicester: IVP, 1964] 59). 
forward with the truth, wherever he may land. Kierkegaard gives an example of this in Sickness Unto Death: 'The self is healthy and free from despair only when, precisely by having despaired, it rests transparently in God'.22

We may well feel that a view of truth which is more propositional than personal is easier to live with. But it was not Kierkegaard's calling to make things easier. We may wish to stay near the edge of the ocean of truth, where 'the wader feels his way with his foot, lest he get beyond his depth' (p. 208). But Kierkegaard would have us launch out and face 'the peril of lying upon the deep, the seventy thousand fathoms, in order there to find God'.

22Sickness unto Death, edited and translated by Howard V. Hong and Edna H. Hong (Princeton: Princeton University Press, 1983) 30. Cf. what Macquarrie says about Karl Jaspers: 'Jaspers...became interested in what he calls the "limit situations" of life, those situations where we come up against a wall, as it were: the human resources are exhausted and a "shattering" or "foundering" takes place. However, the conclusion is not nihilism, for it is in precisely such situations, according to Jaspers, that there opens to us the reality of Transcendence' (John Macquarrie, Existentialism [Harmondsworth: Penguin Books, 1973] 56). 